\title{
Bioethanol Production from Sugarcane Bagasse by a Novel Brazilian Pentose Fermenting Yeast Scheffersomyces shehatae UFMG-HM 52.2: Evaluation of Fermentation Medium
}

\author{
F. A. F. Antunes, ${ }^{1}$ A. K. Chandel, ${ }^{1}$ T. S. S. Milessi, ${ }^{1}$ J. C. Santos, ${ }^{1}$ \\ C. A. Rosa, ${ }^{2}$ and S. S. da Silva ${ }^{1}$ \\ ${ }^{1}$ Department of Biotechnology, School of Engineering of Lorena, University of Sao Paulo, 12.602-81 Lorena, SP, Brazil \\ ${ }^{2}$ Department of Microbiology, Federal University of Minas Gerais, Belo Horizonte, MG, Brazil
}

Correspondence should be addressed to S. S. da Silva; silviosilverio@gmail.com

Received 11 February 2014; Accepted 15 April 2014; Published 27 May 2014

Academic Editor: Diego T. Santos

Copyright (C) 2014 F. A. F. Antunes et al. This is an open access article distributed under the Creative Commons Attribution License, which permits unrestricted use, distribution, and reproduction in any medium, provided the original work is properly cited.

\begin{abstract}
Bioconversion of hemicellulosic sugars into second generation $(2 \mathrm{G})$ ethanol plays a pivotal role in the overall success of biorefineries. In this study, ethanol production performance of a novel xylose-fermenting yeast, Scheffersomyces shehatae UFMG-HM 52.2, was evaluated under batch fermentation conditions using sugarcane bagasse (SB) hemicellulosic hydrolysate as carbon source. Dilute acid hydrolysis of SB was performed to obtain sugarcane bagasse hemicellulosic hydrolysate (SBHH). It was concentrated, detoxified, and supplemented with nutrients in different formulations to prepare the fermentation medium to the yeast evaluation performance. S. shehatae UFMG-HM 52.2 (isolated from Brazilian Atlantic rain forest ecosystem) was used in fermentations carried out in Erlenmeyer flasks maintained in a rotator shaker at $30^{\circ} \mathrm{C}$ and $200 \mathrm{rpm}$ for $72 \mathrm{~h}$. The use of a fermentation medium composed of SBHH supplemented with $5 \mathrm{~g} / \mathrm{L}$ ammonium sulfate, $3 \mathrm{~g} / \mathrm{L}$ yeast extract, and $3 \mathrm{~g} / \mathrm{L}$ malt extract resulted in $0.38 \mathrm{~g} / \mathrm{g}$ of ethanol yield and $0.19 \mathrm{~g}$ L.h of volumetric productivity after $48 \mathrm{~h}$ of incubation time.
\end{abstract}

\section{Introduction}

Biofuels have gained important place on the world stage, due to their sustainability and the fast depletion rate of fossil fuels. Brazil is the second largest ethanol producer (23.6 billion liters in 2012/2013) in the world by alcoholic fermentation directly from the juice or from the molasses obtained in sugar production facilities $[1,2]$. During the extraction of sugarcane juice from the stem, sugarcane bagasse $(\mathrm{SB})$ is generated in high amount. According to the Brazilian National Supply Company (CONAB) [1], the sugarcane production correspondent to the 2013/2014 harvest year is about 652 millions of metric tons. These values are correspondent to about 174 millions of metric tons of SB, considering the proportion indicated by Procknor [3]. Around 75-90\% of the SB is used in heat and electricity generation in sugarcane processing industries. Remaining SB may serve as an excellent raw material for second generation $(2 G)$ ethanol production due to the presence of high amount of carbohydrates such as glucose and xylose [4].

In first generation ethanol production technology, Saccharomyces cerevisiae is the most widely used microorganism for the fermentation of sucrose available in the juice or molasses into ethanol. This yeast can also be used for $2 \mathrm{G}$ ethanol production from glucose solution obtained by pretreatment of cellulosic fraction of SB $[4,5]$.

For the economic ethanol production from $\mathrm{SB}$, it is equally important to consider hemicellulosic fraction along with cellulosic part of cell wall. Hemicellulose represents about one-third of the carbohydrate fraction available in SB [4]. This macromolecular fraction is rich in pentose residues, mainly xylose, which are not fermented by native $S$. cerevisiae. However, there are some microorganisms able to ferment xylose to ethanol or other products [6]. The use of xylose metabolizing microorganism will increase in the global yield of ethanol in sugarcane based biorefineries. 
Dilute acid hydrolysis is an efficient process for the hemicellulose depolymerization into variety of priority pentose sugars such as arabinose and mainly xylose. The remaining solid fraction is known as cellulignin which can be hydrolysed into glucose from the cellulose fraction by cellulase enzymes [5]. Hemicellulose depolymerization by dilute acid hydrolysis yields primarily xylose and other sugar monomers, although some other byproducts considering inhibitors to microbial metabolism, such as furans, 5-hydroxymethylfurfurals, phenolics, and weak acids [7]. Therefore, it is necessary to reduce the concentration of these inhibitors prior to using the hemicellulosic hydrolysate into ethanol via microbial fermentation. Calcium oxide mediated neutralization of hydrolysate followed by activated charcoal treatment efficiently removes the inhibitors [8].

For the production of hemicellulosic ethanol, Scheffersomyces shehatae (Syn. Candida shehatae) has been considered a promising microorganism which provides high ethanol productivities [9]. However, a balanced nutrient supplementation is required for the optimal growth of $S$. shehatae for the production of ethanol with desired yield and productivities. In this work, ethanol production from sugarcane bagasse hemicellulosic hydrolysate was evaluated, using the yeast S. shehatae UFMG-HM 52.2 in different fermentation medium.

\section{Materials and Methods}

2.1. Raw Material and Preparation of Hemicellulose Hydrolysate. Sugarcane bagasse was kindly provided by Usina São Francisco located in Sertaozinho, SP, Brazil. The hemicellulosic hydrolysate was prepared in hydrolysis reactor $(200 \mathrm{~L})$ using $\mathrm{H}_{2} \mathrm{SO}_{4} 98 \%$ as a catalyst in a ratio of $100 \mathrm{mg} \mathrm{H}_{2} \mathrm{SO}_{4} / \mathrm{g}$ of dry material for 20 minutes at $121^{\circ} \mathrm{C}$ [10-12]. The hydrolysate was separated from solid material via filtration. The hydrolysate was concentrated by vacuum evaporator (3-fold concentrated) under reduced pressure at $70^{\circ} \mathrm{C}$ in a $32 \mathrm{~L}$ capacity concentrator. The concentrated hydrolysate was then detoxified following the methodology established by Alves et al. [8] which consists of an overliming and activated charcoal combination.

2.2. Inoculum Preparation. The yeast Scheffersomyces shehatae UFMG-HM 52.2, isolated from Atlantic rain forest in Brazil and kindly provided by the Culture Collection of Microorganisms and Cells of the Federal University of Minas Gerais (UFMG), was used in all fermentations assays. For the inoculum preparation, a loopful of stock culture was transferred to Erlenmeyer flasks of $125 \mathrm{~mL}$ containing $50 \mathrm{~mL}$ of synthetic medium composed of $30.0 \mathrm{~g} / \mathrm{L}$ xylose, $10.0 \mathrm{~g} / \mathrm{L}$ yeast extract, and $20.0 \mathrm{~g} / \mathrm{L}$ of peptone. Cells were grown in an incubator at $200 \mathrm{rpm}$ and $30^{\circ} \mathrm{C}$ for $24 \mathrm{hrs}$. Following the $24 \mathrm{~h}$ growth, the fermented broth was centrifuged at $2000 \times \mathrm{g}$ for $20 \mathrm{~min}$. Then, the cells were washed and resuspended in sterile distilled water. The inoculum was standardized to a concentration of $0.5 \mathrm{~g} / \mathrm{L}$, according to a standard curve plotted cells concentration $(\mathrm{g} / \mathrm{L})$ versus optical density (O.D at $600 \mathrm{~nm}$ ).
2.3. Fermentations. For assays of fermentation using S. shehatae UFMG-HM 52.2, medium composed of hydrolysate supplemented with different compositions for the cultivation were used. The choice of the fermentation medium was based on literature data considering the criteria of simplicity of medium, less number of components, cost, and ethanol production efficiency, from works using different strains for S. shehatae. Thus, different media formulations were chosen based on the fermentation medium used by Parekh et al. [13], Ge et al. [14], and Sun and Tao [15]. The composition of media is shown in Table 1.

Flasks were maintained in a rotator shaker (Innova 4000 Incubator Shaker, New Brunswick Scientific, Enfield, CT, USA) at $30^{\circ} \mathrm{C}$ and $200 \mathrm{rpm}$ for $72 \mathrm{~h}$. Samples were periodically collected to determine the residual sugars and ethanol and biomass production.

Ethanol yield $\left(Y_{\mathrm{P} / \mathrm{S}}\right)(\mathrm{g} / \mathrm{g})$ was considered as the ratio between ethanol production $(\mathrm{g} / \mathrm{L})$ and sugars consumption $(\mathrm{g} / \mathrm{L})$, while ethanol volumetric productivity $\left(Q_{p}\right)(\mathrm{g} / \mathrm{L} \cdot \mathrm{h})$ was the ratio between ethanol production $(\mathrm{g} / \mathrm{L})$ and fermentation time $(\mathrm{h})$. Biomass yield $\left(Y_{\mathrm{P} / \mathrm{X}}\right)(\mathrm{g} / \mathrm{g})$ was considered as the ratio between biomass production $(\mathrm{g} / \mathrm{L})$ and sugars consumption $(\mathrm{g} / \mathrm{L})$, while biomass volumetric productivity $\left(Q_{x}\right)(g / L \cdot h)$ was the ratio between biomass production $(\mathrm{g} / \mathrm{L})$ and fermentation time (h).

2.4. Scanning Electron Microscope (SEM). The SEM analysis of original and dilute sulfuric acid pretreated SB was performed as described by Kristensen et al. [16]. Original and dilute acid pretreated SB was distributed on a $12 \mathrm{~mm}$ glass cover slip coated with poly-L-lysine (Sigma Diagnostics, S.P. Brazil). The dried sections were mounted on aluminum stubs, sputter-coated (JEOL JFC - 1600) with a gold layer, and used for scanning. The prepared samples were scanned and imaged using Hitachi S520 scanning electron microscope (Hitachi, Tokyo, Japan).

2.5. Analytical Methods. Natural SB and cellulignin (dilute acid pretreated SB) were characterized for the presence of main chemical constituents (cellulose, hemicellulose, lignin, and ashes) following the methodology described by Gouveia et al. [17]. The determination of compounds in hemicellulosic hydrolysate was verified by high performance liquid chromatography (HPLC). The content of glucose, xylose, arabinose, acetic acid, and ethanol was verified in chromatograph Schimadzu LC-10 AD (Kyoto, Japan) with column equipped with BIO-RAD Aminex HPX-87H (300 $\times 7.8 \mathrm{~mm}$ ) coupled to refractive index detector (RID-6A), with $0.01 \mathrm{~N}$ sulfuric acid as an eluent at a flow rate of $0.6 \mathrm{~mL} / \mathrm{min}$, column temperature of $45^{\circ} \mathrm{C}$, and injected volume of $20 \mu \mathrm{L}$. For these analysis, samples were previously filtered through Sep Pak C18 filter. The determination of furfural and 5-hydroxymethylfurfural was obtained in chromatograph Schimadzu-LC 10 AD (Kyoto, Japan), with column HP-RP18 $(200 \times 4.6 \mathrm{~mm})$, coupled to a ultraviolet detector SPD-10A UV-VIS in a wavelength of $276 \mathrm{~nm}$, with eluent acetonitrile/water $(1: 8)$ and $1 \%$ of acetic acid. The used flow was $0.8 \mathrm{~mL} / \mathrm{min}$, the column temperature was 
TABLE 1: Medium composition for the fermentation of S. shehatae UFMG-HM 52.2 for ethanol production. Nutrients were added to detoxified hemicellulosic sugarcane bagasse hydrolysate that was used as sole carbon source in all fermentation media.

\begin{tabular}{|c|c|c|}
\hline $\begin{array}{l}\text { Fermentation } \\
\text { medium }\end{array}$ & Composition & Reference \\
\hline Medium \#A & $\begin{array}{l}5 \mathrm{~g} / \mathrm{L} \text { of ammonium sulfate } \\
3 \mathrm{~g} / \mathrm{L} \text { of yeast extract } \\
3 \mathrm{~g} / \mathrm{L} \text { of malt extract }\end{array}$ & Parekh et al. [13] \\
\hline Medium \#B & $\begin{array}{l}5 \mathrm{~g} / \mathrm{L} \text { of peptone } \\
3 \mathrm{~g} / \mathrm{L} \text { of yeast extract } \\
3 \mathrm{~g} / \mathrm{L} \text { of malt extract } \\
\end{array}$ & Parekh et al.[13] \\
\hline Medium \#C & $\begin{array}{l}1.73 \mathrm{~g} / \mathrm{L} \text { of ammonium sulfate } \\
3.56 \mathrm{~g} / \mathrm{L} \text { of potassium phosphate } \\
\text { monobasic } \\
2.62 \mathrm{~g} / \mathrm{L} \text { of yeast extract }\end{array}$ & Ge et al. [14] \\
\hline Medium \#D & $\begin{array}{l}3 \mathrm{~g} / \mathrm{L} \text { of yeast extract } \\
0.25 \mathrm{~g} / \mathrm{L} \text { of urea } \\
0.25 \mathrm{~g} / \mathrm{L} \text { of calcium chloride } \\
0.25 \mathrm{~g} / \mathrm{L} \text { of magnesium sulfate } \\
2.5 \mathrm{~g} / \mathrm{L} \text { of potassium phosphate } \\
\text { monobasic }\end{array}$ & Sun and Tao [15] \\
\hline
\end{tabular}

$25^{\circ} \mathrm{C}$, and the volume injected was $20 \mu \mathrm{L}$. For these analyses, all samples were previously filtered in membrane Minisart $0.22 \mu \mathrm{m}$ (Sartorius, Goettingen, Germany).

The cells concentration was determined by turbidimetry using spectrophotometer (Beckman DU 640 B Fullerton, CA) at wavelength of $600 \mathrm{~nm}$ and correlated with the dry weight of cells $(\mathrm{g} / \mathrm{L})$ through a calibration curve. The measurements were made on diluted cell suspensions, after centrifugation, washing, and resuspension of cells in distilled water.

\section{Results and Discussion}

3.1. Sugarcane Bagasse and Hemicellulosic Hydrolysate Characterization. SB was submitted to dilute acid hydrolysis and, after this step, the solid fraction (cellulignin) was separated from hemicellulosic hydrolysate. Cellulignin was also characterized for the chemical composition.

The chemical composition of sugarcane bagasse cell wall (original) and cellulignin was characterized for its main constituents. Figure 1 presents the cell wall composition of original and dilute acid pretreated bagasse.

The cell wall composition of SB is difficult to compare with the existing reports in literature due to the differences in origin, cultivation methods, climate conditions, and analytical methods used for the characterization [4]. For example, cellulose content in the original sugarcane bagasse was 39.52\% (Figure 1) while Rocha et al. [18] and Aguilar et al. [19] observed $45.5 \%$ and $38.9 \%$ of cellulose, respectively. Similarly, hemicellulose content in the original SB was $25.63 \%$ (Figure 1); however, Rocha et al. [18] and Martín et al. [20] observed $27 \%$ hemicellulose in their analysis. The lignin content in the raw SB was $30.36 \%$ (Figure 1), while Philippini [21] reported $34.42 \%$ of lignin in native SB. According to Ek et al. [22], there is a variation in the compounds concentrations

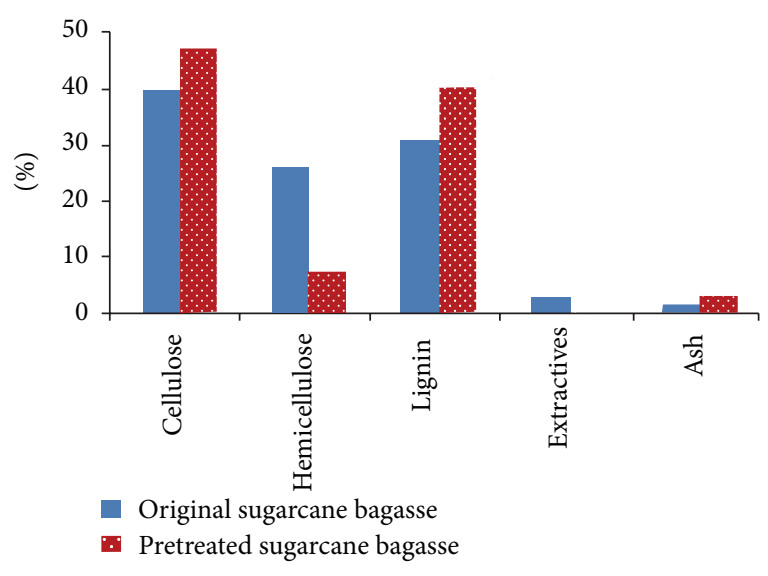

FIGURE 1: Composition profile (\% dry weight) of original and dilute sulfuric acid pretreated sugarcane bagasse (diluted $\mathrm{H}_{2} \mathrm{SO}_{4} 98 \%, 20$ minutes at $\left.121^{\circ} \mathrm{C}\right)$.

of the same biomass species due to the variation in age of the plant, genetic factors, and growth conditions, as well as climatic and geographical factors. In general, Brazilian sugarcane bagasse variety has cellulose concentrations in the ranges of $38-46 \%$, hemicellulose in 19-32\%, lignin in $19-31 \%$, and ash and extractives between $1.0-3 \%$ and $6.9 \%$, respectively [4].

After acid hydrolysis of SB, the solid fraction was separated from hemicellulosic hydrolysate. Pretreated SB was also characterized for the chemical composition and it was observed a reduction of $72 \%$ of hemicellulose, showing the effectiveness of dilute acid hydrolysis for this polymeric fraction solubilization. This result was in close agreement with the study of Philippini [21] who obtained $65 \%$ to $85 \%$ reduction in hemicellulose amount from the bagasse of various sugarcane species.

Dilute acids hydrolysis acts specifically on hemicellulose making the overall structure quite disorganized due to the disruption of this polymeric fraction. Scanning electron microscopic (SEM) analysis shows the surface of original SB and after dilute acid hydrolysis which clearly reveals the change in cell wall surface morphology at various magnifications (Figure 2).

As shown in Figure 2, original SB micrographs show the rigidness and compactness of cell wall and the acid pretreated SB micrographs show the disruption in bagasse surface due to degradation of hemicellulose during dilute acid hydrolysis of SB. Cell wall surface shows disruption and roughness due to the removal of hemicellulose and lignin delocalization. According to Alvira et al. [5], after acid hydrolysis, the SB is structurally modified. Fibers of SB break down after acid hydrolysis. Milessi et al. [12] also observed the similar appearance of cell wall after dilute acid hydrolysis of SB.

The liquid solubilized fraction (crude hemicellulosic hydrolysate) was concentrated by vacuum evaporation in order to increase the sugars concentration. The concentrated hydrolysate was subsequently detoxified by sequential calcium oxide mediated neutralization followed by activated 

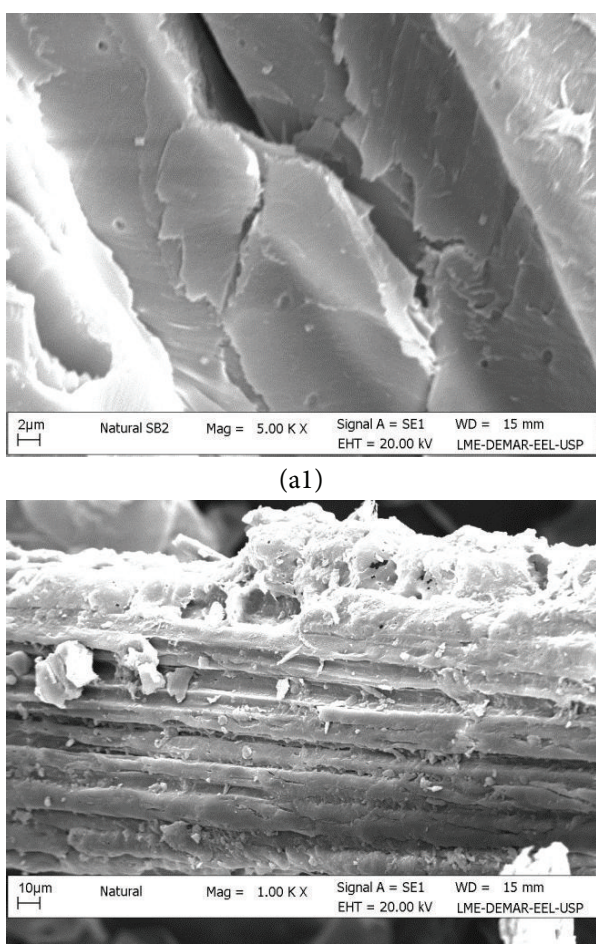

(a2)

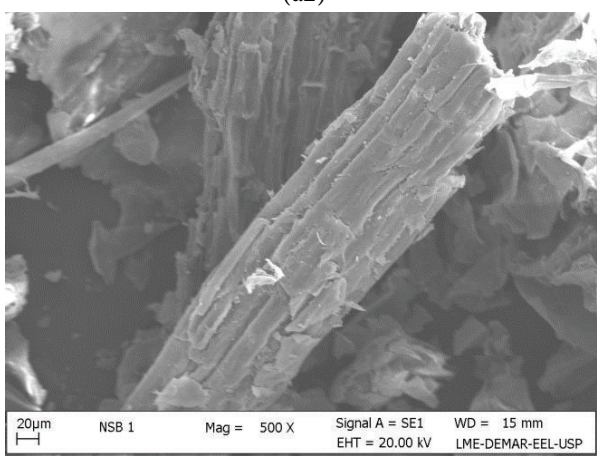

(a3)

(a)

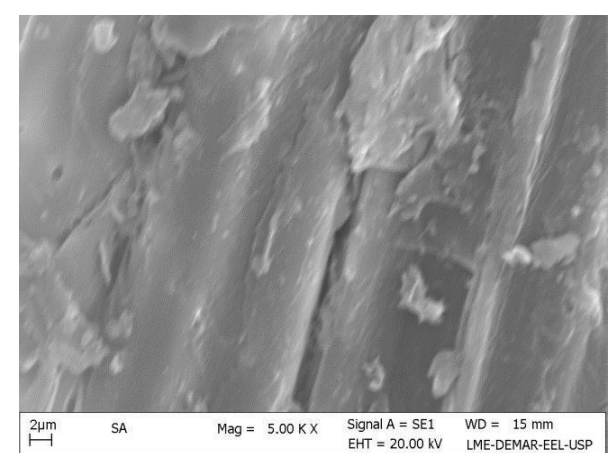

(b1)

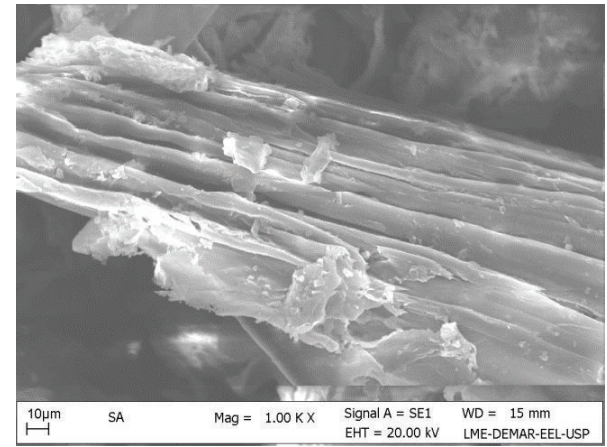

(b2)

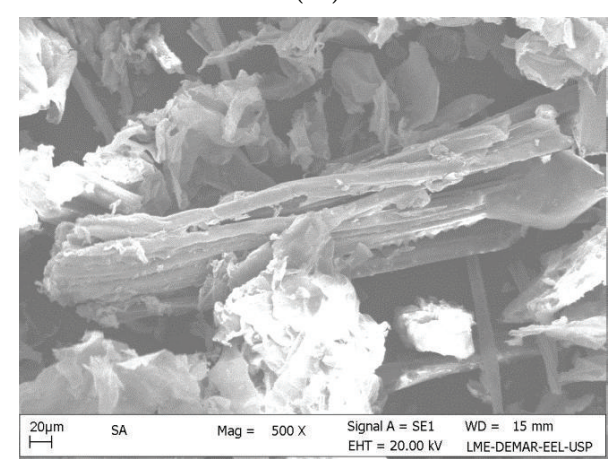

(b3)

(b)

FIGURE 2: Scanning electron microscopic (SEM) analysis showing the surface images of sugarcane before (a) and after (b) dilute acid pretreatment (diluted $\mathrm{H}_{2} \mathrm{SO}_{4} 98 \%, 20$ minutes at $\left.121^{\circ} \mathrm{C}\right)$. (a1)/(b1), (a2)/(b2), and (a3)/(b3) are referents to a magnification of 500, 1000, and 5000x, respectively.

charcoal treatment. The composition of original, concentrated, and detoxified hemicellulosic hydrolysate is shown in Table 2.

The hydrolysis conditions promoted the release of xylose significantly higher than glucose (concentration below the detection limit), indicating greater susceptibility of hemicellulose than cellulose to hydrolysis conditions. This behavior was expected due to the fact that the structure of the hemicellulose is hydrolyzed easily than cellulose [11].

Concentrated hydrolysate showed variations in all compounds concentration. Concentration of xylose present in crude hydrolysate $(10.09 \mathrm{~g} / \mathrm{L})$ increased approximately 3.5 times after evaporation under vacuum $(37.43 \mathrm{~g} / \mathrm{L})$. After concentration, it was observed 0.39 and $2.72 \mathrm{~g} / \mathrm{L}$ of glucose and arabinose, indicating that both were present in the crude hydrolysate, but in low levels (below the detection limits of any compounds by the HPLC used method).

Detoxification strategy (calcium oxide mediated neutralization + activated charcoal) was used considering the previous experience in our lab showing that nondetoxified hemicellulosic hydrolysate inhibitors levels interfere in fermentation performance. Actually, in despite of some reduction in sugar level after detoxification procedure, it was found effective in reducing inhibitors, particularly furfural and hydroxymethylfurfural concentration of $5.7 \cdot 10^{-3} \mathrm{~g} / \mathrm{L}$ to $5.9 \cdot 10^{-4} \mathrm{~g} / \mathrm{L}$ and $2.3 \cdot 10^{-2} \mathrm{~g} / \mathrm{L}$ to $1 \cdot 10^{-3} \mathrm{~g} / \mathrm{L}$, respectively, when compared the original and detoxified hydrolysates. According to van Zyl et al. [23], this removal is related to the 
TABLE 2: Composition of original, concentrated, and detoxified hydrolysate.

\begin{tabular}{lccc}
\hline Compounds & $\begin{array}{c}\text { Original } \\
\text { hydrolysate } \\
(\mathrm{g} / \mathrm{L})\end{array}$ & $\begin{array}{c}\text { Concentrated } \\
\text { hydrolysate } \\
(\mathrm{g} / \mathrm{L})\end{array}$ & $\begin{array}{c}\text { Detoxified } \\
\text { hydrolysate } \\
(\mathrm{g} / \mathrm{L})\end{array}$ \\
\hline Glucose & $\mathrm{n} / \mathrm{d}^{*}$ & 0.39 & 0.31 \\
Xylose & 10.9 & 37.43 & 31 \\
Arabinose & $\mathrm{n} / \mathrm{d}^{*}$ & 2.72 & 2.31 \\
Acetic acid & 0.53 & 1.83 & 1.26 \\
5-HMF & $5.7 \cdot 10^{-3}$ & $1 \cdot 10^{-3}$ & $5 \cdot 10^{-4}$ \\
Furfural & $2.3 \cdot 10^{-3}$ & $2 \cdot 10^{-3}$ & $1 \cdot 10^{-3}$ \\
\hline
\end{tabular}

${ }^{*}$ Nondetected.

association of inhibitory compounds with bivalent calcium ions, due to the precipitation.

The reduction in acetic acid concentration in the detoxification pathway was around $30 \%$, showing a final concentration of $1.269 \mathrm{~g} / \mathrm{L}$. According to Chandel et al. [24], the presence of small amount of acetic acid (until $2.0 \mathrm{~g} / \mathrm{L}$ ) in the hydrolysate can improve the ethanol production during fermentation. However, the tolerance of microorganisms to acetic acid depends on microbial species and cultivation conditions [25].

3.2. Screening of Fermentation Medium. Four different media were chosen based on their simplicity and low number of compounds and related to good results found on literature to the ethanol production using the yeast $S$. shehatae. Regarding the chosen formulations, we highlight the use of yeast extract in all media, once this compound has been extensively used as an organic nitrogen source for ethanol production by yeasts. Yeast extract contains about $12 \%$ of total nitrogen (Synth, Diadema, Brazil). This compound is crucial to supplement hemicellulosic hydrolysates using cells of S. shehatae for $2 \mathrm{G}$ ethanol production. Silva et al. [26] reported that among different nitrogen sources, yeast extract is one of the most important sources for the production of ethanol. Maruthai et al. [27] also concluded that the yeast extract and ammonium sulfate have most significant effect on ethanol production from cashew apple juice by the yeast Saccharomyces diastaticus.

The different fermentation media (detoxified SB hydrolysate + nutrients supplementation) were tested during the fermentation by yeast S. shehatae UFMG-HM 52.2 and the fermentation profiles obtained using these media are shown in Figure 3.

The maximum ethanol concentration was observed after 48 hours of incubation for all evaluated fermentation media. After $48 \mathrm{~h}$ of incubation, a decrease in ethanol concentration was observed. This behavior can be attributed to total fermentable sugars utilization by yeast, occurring ethanol assimilation as carbon source. After this time, cell growth was also lower in comparison with the growth of cells using carbohydrates as a sole carbon source. The use of ethanol as a carbon source after depletion of sugars was reported in previous studies using the yeast $S$. shehatae [24, 28]. Ethanol production results (ethanol yield and productivities) from each experiment are shown in Figure 4.

Other fermentative parameters such as biomass yield, biomass productivities, xylose consumption, and acetic acid consumption have been presented in Table 3.

In all fermentation experiments, approximately $100 \%$ consumption of initial sugar was found. Medium \#A showed ethanol yield of approximately $0.38 \mathrm{~g} / \mathrm{g}$ and productivity of $0.19 \mathrm{~g} / \mathrm{L} \cdot \mathrm{h}$ (Figure 4). Parekh et al. [13] evaluated the ethanol production profile of $S$. shehatae ATCC 22984 utilizing wood hemicellulosic hydrolysate and obtained ethanol yield of $0.45 \mathrm{~g} / \mathrm{g}$. However, it is difficult to compare the ethanol production parameters of the same microorganism grown in different kind of lignocellulose hydrolysates due to the change in cultivation conditions, cultivation methods, and hydrolysate profile [24]. For instance, the same microorganism (S. shehatae UFMG-HM 52.2 when grown in hemicellulosic hydrolysate of SB obtained after oxalic acid pretreatment and supplemented with $3.0 \mathrm{~g} / \mathrm{L}$ of yeast extract, $3.0 \mathrm{~g} / \mathrm{L}$ of malt extract, and $5.0 \mathrm{~g} / \mathrm{L}$ of ammonium sulfate) showed ethanol yield of $0.35 \mathrm{~g} / \mathrm{g}$ [28]. This medium is considered effective due to the presence of yeast extract and ammonium sulfate, compounds easily found in the market and largely used in fermentation medium supplementation [27].

Medium \#B designed by Parekh et al. [13] was also tested in fermentation assays, showing ethanol yield $\left(Y_{\mathrm{P} / \mathrm{S}}\right)$ of $0.36 \mathrm{~g} / \mathrm{g}$ and $Q_{p}$ of $0.2 \mathrm{~g} / \mathrm{L} \cdot \mathrm{h}$ (Figure 4). Canilha et al. [29] also used this medium in SBHH for ethanol production, but using S. stipitis DSM 3651, and reported $Y_{\mathrm{P} / \mathrm{S}}$ of $0.30 \mathrm{~g} / \mathrm{g}$ and $Q_{p}$ of $0.13 \mathrm{~g} / \mathrm{L} \cdot \mathrm{h}$. Although these results were obtained with a different yeast, those authors have indicated the potential of these media formulation. This feature was also demonstrated by using $S$. shehatae UFMG-HM 52.2 that in our work resulted in a higher value of $Y_{\mathrm{P} / \mathrm{S}}$ compared to them. Medium \#A and \#B are comprised of malt extract which contains $73.1 \%$ of maltose, glucose, and fructose [30].

Medium \#C was used based on the study of $\mathrm{Ge}$ et al. [14], who evaluated the ethanol production performance of S. shehatae HDYXHT-01 from xylose as main carbon source. In this study, ethanol yield was $0.41 \mathrm{~g} / \mathrm{g}$, close to the value obtained in the present work, where $0.38 \mathrm{~g} / \mathrm{g}$ and $Q_{p}$ of $0.2 \mathrm{~g} / \mathrm{L} \cdot \mathrm{h}$ were obtained from $S$. shehatae UFMG-HM 52.2 using medium \#C.

Fermentation experiments using medium \#D showed approximately $Y_{\mathrm{P} / \mathrm{S}}$ of $0.23 \mathrm{~g} / \mathrm{g}$ and $Q_{p}$ of $0.12 \mathrm{~g} / \mathrm{L} \cdot \mathrm{h}$. Previously, this medium was used by Sun and Tao [15] for ethanol production by $S$. shehatae CICC 1766 from rice straw hydrolysate at $\mathrm{pH} 5.5$ and achieved $Y_{\mathrm{P} / \mathrm{s}}$ and $Q_{p}$ of $0.31 \mathrm{~g} / \mathrm{g}$ and $0.175 \mathrm{~g} / \mathrm{L} \cdot \mathrm{h}$, respectively. This nutritional medium showed no major change in ethanol production compared to other fermentation media \#A, \#B, and \#C. It is noteworthy that this medium does not have peptone or ammonium sulfate, which contains about 11\% (Sigma-Aldrich, São Paulo, Brazil) and $21 \%$ (Isquisa Chemical, Cordoba, Mexico) of total nitrogen, respectively, suggesting the importance of these nutrients to the cultivation of S. shehatae UFMG-HM 52.2.

In the present study, a small concentration of L-arabinose (about $2 \mathrm{~g} / \mathrm{L}$ ) was found in fermentation broth. L-arabinose 

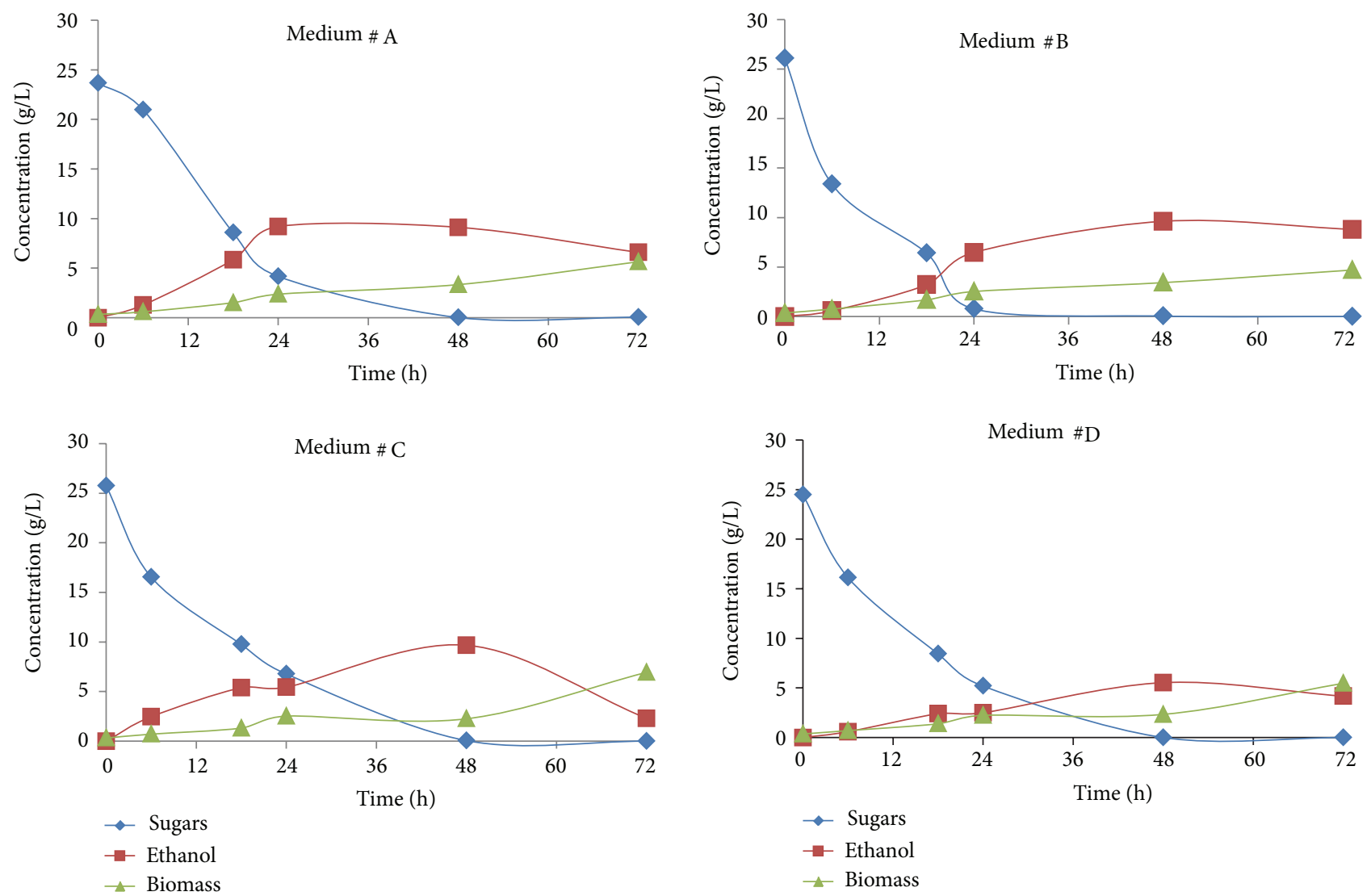

FIGURE 3: Fermentation of SBHH (sugarcane bagasse hemicellulosic hydrolysate) supplemented with different nutritional components using yeast Scheffersomyces shehatae UFMG-HM 52.2. Medium \#A: $5 \mathrm{~g} / \mathrm{L}$ ammonium sulfate, $3 \mathrm{~g} / \mathrm{L}$ yeast extract, $3 \mathrm{~g} / \mathrm{L}$ of malt extract [13]; medium \#B: $5 \mathrm{~g} / \mathrm{L}$ peptone, $3 \mathrm{~g} / \mathrm{L}$ yeast extract, $3 \mathrm{~g} / \mathrm{L}$ malt extract [13]; medium \#C: $1.73 \mathrm{~g} / \mathrm{L}$ ammonium sulfate, $3.56 \mathrm{~g} / \mathrm{L}$ potassium phosphate monobasic, $2.62 \mathrm{~g} / \mathrm{L}$ yeast extract [14]; medium \#D: $3 \mathrm{~g} / \mathrm{L}$ yeast extract, $0.25 \mathrm{~g} / \mathrm{L}$ of urea, $0.25 \mathrm{~g} / \mathrm{L}$ calcium chloride, $0.25 \mathrm{~g} / \mathrm{L}$ magnesium sulfate, $2.5 \mathrm{~g} / \mathrm{L}$ potassium phosphate monobasic [15]. In all media, the nutrients were added to detoxified hemicellulosic sugarcane bagasse hydrolysate, used as sole carbon source.

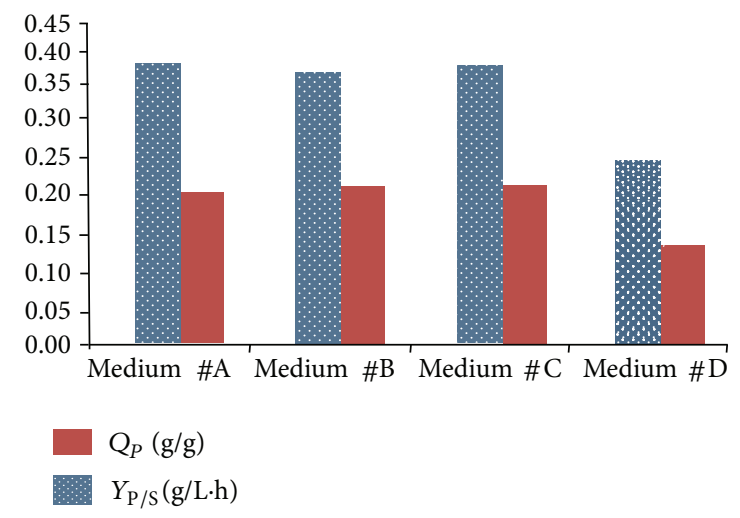

FIGURE 4: Ethanol yield $\left(Y_{\mathrm{P} / \mathrm{S}}\right)$ and productivity $\left(Q_{p}\right)$ after the fermentation of SBHH by $S$. shehatae UFMG-HM 52.2 using different nutritional medium (medium $\# \mathrm{~A}, \# \mathrm{~B}$, $\# \mathrm{C}$, and $\# \mathrm{D}$ ). Experiments were carried out in replicates and standard deviation is within $5 \%$.

was not utilized by S. shehatae UFMG-HM 52.2. SpencerMartins [31] also found no consumption of mannose and
TABLE 3: Fermentative parameters $\left(Y_{\mathrm{X} / \mathrm{S}}, Q_{x}\right.$ xylose consumption (\%), and final $\mathrm{pH}$ of broth) of nutritional medium screening of $S$. shehatae UFMG-HM 52.2 SBHH fermentation (medium \#A, \#B, \#C, and \#D).

\begin{tabular}{lcccc}
\hline & $\begin{array}{c}Y_{\mathrm{X} / \mathrm{S}} \\
(48 \mathrm{~h}) \\
(\mathrm{g} / \mathrm{g})\end{array}$ & $\begin{array}{c}\mathrm{Q}_{x} \\
(48 \mathrm{~h}) \\
(\mathrm{g} / \mathrm{L} \cdot \mathrm{h})\end{array}$ & $\begin{array}{c}\text { Consumed sugars } \\
(48 \mathrm{~h}) \\
(\%)\end{array}$ & Final $\mathrm{pH}$ \\
\hline Medium \#A & 0.125 & 0.069 & $100 \%$ & 6.5 \\
Medium \#B & 0.115 & 0.071 & $99.84 \%$ & 6.9 \\
Medium \#C & 0.085 & 0.052 & $99.79 \%$ & 6.2 \\
Medium \#D & 0.080 & 0.048 & $100 \%$ & 6.2 \\
\hline
\end{tabular}

arabinose by S. shehatae. Acetic acid concentration was found to be assimilated by $S$. shehatae after $48 \mathrm{hs}$ of incubation resulting in increasing the $\mathrm{pH}$ of fermentation broth. Felipe et al. [32] have also reported use of acetic acid as carbon source for yeast. However, the concentration of acetic acid for tolerance of microorganisms may vary according to the species used and culture conditions [25]. 
Fermentation media \#A, \#B, and \#C showed similar ethanol yield (about $0.37 \mathrm{~g} / \mathrm{g}$ ) and productivity (about $0.20 \mathrm{~g} / \mathrm{L} \cdot \mathrm{h})$. Medium \#D, on the other hand, showed lower levels of ethanol yield $(0.23 \mathrm{~g} / \mathrm{g})$ and production $(0.12 \mathrm{~g} / \mathrm{L} \cdot \mathrm{h})$ compared with the other media. The differences among the results of ethanol production among the evaluated media were not significant, according to the Tukey's test carried out considering the replicates of the experiments. In this analysis, only medium 4 has an indicative of its lower performance, with significant difference observed with relation to the other media $(P<0.15)$.

Biomass volumetric productivity $\left(Q_{x}\right)$ and biomass yields $\left(Y_{\mathrm{P} / \mathrm{X}}\right)$ were similar for all fermentation assays (about $0.06 \mathrm{~g} / \mathrm{L} \cdot \mathrm{h}$ and $0.10 \mathrm{~g} / \mathrm{g}$, resp.). It is interesting to note that $Y_{\mathrm{X} / \mathrm{S}}$ and $Q_{x}$ were lower than $Y_{\mathrm{P} / \mathrm{S}}$ and $Q_{p}$, indicating that metabolism of the yeast was directed to the production of ethanol in all tests. Among all the fermentation media investigated, medium \#A revealed high values of ethanol yield $(0.38 \mathrm{~g} / \mathrm{g})$ and productivity $(0.19 \mathrm{~g} / \mathrm{L} \cdot \mathrm{h})$. This fermentation medium formulation is cheap and simple and could be an ideal feed to grow the S. shehatae UFMG-HM 52.2 at large scale biorefinery operations.

\section{Conclusion}

Four different fermentation media formulations were evaluated for the ethanol production by S. shehatae UFMG-HM 52.2 using sugarcane bagasse hemicellulosic hydrolysate as the main carbon source. Fermentation media \#A, \#B, and \#C showed similar ethanol yield and productivity while medium \#D showed low ethanol production compared to the others. We highlight Medium \#A due its simple composition $(5 \mathrm{~g} / \mathrm{L}$ ammonium sulfate, $3 \mathrm{~g} / \mathrm{L}$ yeast extract, $3 \mathrm{~g} / \mathrm{L}$ of malt extract) that showed ethanol yield of $0.38 \mathrm{~g} / \mathrm{g}$ and productivity of $0.19 \mathrm{~g} / \mathrm{L} \cdot \mathrm{h}$.

\section{Conflict of Interests}

The authors declare that there is no conflict of interests.

\section{Acknowledgments}

The authors gratefully acknowledge the financial support from FAPESP-BIOEN, FAPEMIG, CNPq, and CAPES.

\section{References}

[1] CONAB-Companhia Nacional de Abastecimento, "Acompanhamento da safra brasileira: cana-de-açúcar," Segundo levantamento, 2013, http://www.conab.gov.br/OlalaCMS/uploads/arquivos/13_08_08_09_39_29_boletim_cana_portugues_-abril_2013_lo_lev.pdf.

[2] Ministério da Agricultura, "Acompanhamento da Produção Sucroalcooleira," 2014, http://www.agricultura.gov.br/desenvolvimento-sustentavel/agroenergia.

[3] C. Procknor, "Subprodutos; o bagaço," STAB, Açúcar, Álcool e Subprodutos, vol. 18, no. 4, p. 14, 2000.
[4] L. Canilha, A. K. Chandel, T. S. S. Milessi et al., "Bioconversion of sugarcane biomass into ethanol: an overview about composition, pretreatment methods, detoxification of hydrolysates, enzymatic saccharification and ethanol fermentation," Journal Biomedicine and Biotechnology, vol. 2012, Article ID 989572, 15 pages, 2012.

[5] P. Alvira, E. Tomás-Pejó, M. Ballesteros, and M. J. Negro, "Pretreatment technologies for an efficient bioethanol production process based on enzymatic hydrolysis: a review," Bioresource Technology, vol. 101, no. 13, pp. 4851-4861, 2010.

[6] R. M. Cadete, M. A. Melo, and K. J. Dussán, "Diversity and physiological characterization of D-xylose-fermenting yeasts isolated from the Brazilian Amazonian forest," PloS ONE, vol. 7, Article ID e43135, 2012.

[7] A. K. Chandel, S. S. Silva, and O. V. Singh, "Detoxification of lignocellulose hydrolysates: biochemical and metabolic engineering towards white biotechnology," BioEnergy Research, vol. 6, pp. 388-401, 2012.

[8] L. A. Alves, M. G. A. Felipe, J. B. A. E. Silva, S. S. Silva, and A. M. R. Prata, "Pretreatment of sugarcane bagasse hemicellulose hydrolysate for xylitol production by Candida guilliermondii," Applied Biochemistry and Biotechnology A. Enzyme Engineering and Biotechnology, vol. 70-72, pp. 89-98, 1998.

[9] S. E. Martiniano, R. R. Philippini, A. K. Chandel, C. A. Rosa, and S. S. Silva, "Evaluation of rice bran extract as a nitrogen source for improved hemicellulosic etanol production by new xylose fermenting yeasts, isolated from Brazilian forests," Sugar Tech, vol. 16, no. 1, pp. 1-8, 2014.

[10] W. Carvalho, L. Canilha, and S. S. Da Silva, "Semi-continuous xylitol bioproduction in sugarcane bagasse hydrolysate: effect of nutritional supplementation," Brazilian Journal of Pharmaceutical Sciences, vol. 43, no. 1, pp. 47-53, 2007.

[11] F. A. F. Antunes, T. S. S. Milessi, I. Oliveira, A. K. Chandel, and S. S. Silva, "Characterization of sugarcane bagasse hemicellulosic hydrolysate after detoxification with overliming and activated charcoal," in Proceedings of the 20th European Biomass Conference and Exhibition, pp. 1603-1606, Milan, Italy, 2012.

[12] T. S. S. Milessi, F. A. F. Antunes, A. K. Chandel, and S. S. Silva, "Rice bran extract: an inexpensive nitrogen source for the production of $2 \mathrm{G}$ ethanol from sugarcane bagasse hydrolysates," 3 Biotech, vol. 3, pp. 373-379, 2012.

[13] S. R. Parekh, S. Yu, and M. Wayman, "Adaptation of Candida shehatae and Pichia stipitis to wood hydrolysates for increased ethanol production," Applied Microbiology and Biotechnology, vol. 25, no. 3, pp. 300-304, 1986.

[14] J. Ge, G. Liu, X. Yang, H. Sun, H. Ling, and W. Ping, “Optimization of xylose fermentation for ethanol production by Candida shehatae HDYXHT-01," Chinese Journal of Biotechnology, vol. 27, no. 3, pp. 404-411, 2011.

[15] W.-L. Sun and W.-Y. Tao, "Comparison of cell growth and ethanol productivity on different pretreatment of rice straw hemicellulose hydrolysate by using Candida shehatae CICC 1766," African Journal of Microbiology Research, vol. 4, no. 11, pp. 1105-1109, 2010.

[16] J. B. Kristensen, L. G. Thygesen, C. Felby, H. Jørgensen, and T. Elder, "Cell-wall structural changes in wheat straw pretreated for bioethanol production," Biotechnology for Biofuels, vol. 1, article 5, 2008.

[17] E. R. Gouveia, R. T. Nascimento, A. M. Souto-Maior, and G. J. M. Rocha, "Validação de metodologia para a caracterização química de bagaço de cana-de-açúcar," Química Nova, vol. 32, pp. 1500-1503, 2009. 
[18] G. J. M. Rocha, A. R. Gonçalves, B. R. Oliveira, E. G. Olivares, and C. E. V. Rossell, "Steam explosion pretreatment reproduction and alkaline delignification reactions performed on a pilot scale with sugarcane bagasse for bioethanol production," Industrial Crops and Products, vol. 35, no. 1, pp. 274-279, 2012.

[19] R. Aguilar, J. A. Ramírez, G. Garrote, and M. Vázquez, "Kinetic study of the acid hydrolysis of sugar cane bagasse," Journal of Food Engineering, vol. 55, no. 4, pp. 309-318, 2002.

[20] C. Martín, J. Puls, B. Saake, and A. Schreiber, "Effect of glycerol preatreatment on component recovery and enzymatic hydrolysis of sugarcane bagasse," Cellulose Chemistry and Technology, vol. 45, no. 7-8, pp. 487-494, 2011.

[21] R. R. Philippini, Variedades híbridas de bagaço de canade-açúcar: caracterização química e hidrólise enzimática em condições de pré-tratamento diferenciadas [M.S. dissertation], Industrial Biotechnology, School of engineering of Lorena, University of São Paulo, Lorena, SP, Brazil, 2012.

[22] M. Ek, G. Gellerstedt, and G. Henriksson, "Pulp and paper chemistry and technology," in Wood Chemistry and Wood Biotechnology, vol. 1, pp. 1-320, 2009.

[23] C. van Zyl, B. A. Prior, and J. C. du Preez, "Production of ethanol from sugar cane bagasse hemicellulose hydrolyzate by Pichia stipitis," Applied Biochemistry and Biotechnology, vol. 17, no. 13, pp. 357-369, 1988.

[24] A. K. Chandel, R. K. Kapoor, A. Singh, and R. C. Kuhad, "Detoxification of sugarcane bagasse hydrolysate improves ethanol production by Candida shehatae NCIM 3501," Bioresource Technology, vol. 98, no. 10, pp. 1947-1950, 2007.

[25] P. K. Bajwa, T. Shireen, F. Dáoust et al., "Mutans of the pentose-fermenting yeast Scheffersomyces stipitis with improved tolerance to inibitors in hardwoods spent sulfite liquor," Biotechnology Bioengineering, vol. 140, pp. 892-900, 2010.

[26] J. P. A. Silva, S. I. Mussatto, I. C. Roberto, and J. A. Teixeira, "Fermentation medium and oxygen transfer conditions that maximize the xylose conversion to ethanol by Pichia stipitis," Renewable Energy, vol. 37, no. 1, pp. 259-265, 2012.

[27] K. Maruthai, V. Thangavelu, and M. Kanagasabai, "Statistical screening of medium components on ethanol production from cashew apple juice using Saccharomyces diasticus," International Journal of Biological, Life Science and Engineering, vol. 6, pp. 1270-1273, 2012.

[28] A. K. Chandel, F. A. F. Antunes, V. Anjos et al., "Ultra-structural mapping of sugarcane bagasse after oxalic acid fiber expansion (OAFEX) and ethanol production by Candida shehatae and Saccharomyces cerevisiae," Biotechnology for Biofuels, vol. 6, article 4, 2012.

[29] L. Canilha, W. Carvalho, M. D. G. De Almeida Felipe, J. B. De Almeida E Silva, and M. Giulietti, "Ethanol production from sugarcane bagasse hydrolysate using Scheffersomyces stipites," Applied Biochemistry and Biotechnology, vol. 161, no. 1-8, pp. 8492, 2010.

[30] W. Crueger and A. Crueger, Biotechnology: A Textbook of Industrial Microbiology, Sinauer Associates, Sunderland, Mass, USA, 1993.

[31] I. Spencer-Martins, "Transport of sugars in yeasts: implications in the fermentation of lignocellulosic materials," Bioresource Technology, vol. 50, no. 1, pp. 51-57, 1994.

[32] M. G. Felipe, D. C. Vieira, M. Vitolo, S. S. Silva, I. C. Roberto, and I. Manchilha, "Effect of acetic acid on xylose fermentation to xylitol by Candida guilliermondii," Journal of Basic Microbiology, vol. 35, no. 3, pp. 171-177, 1995. 

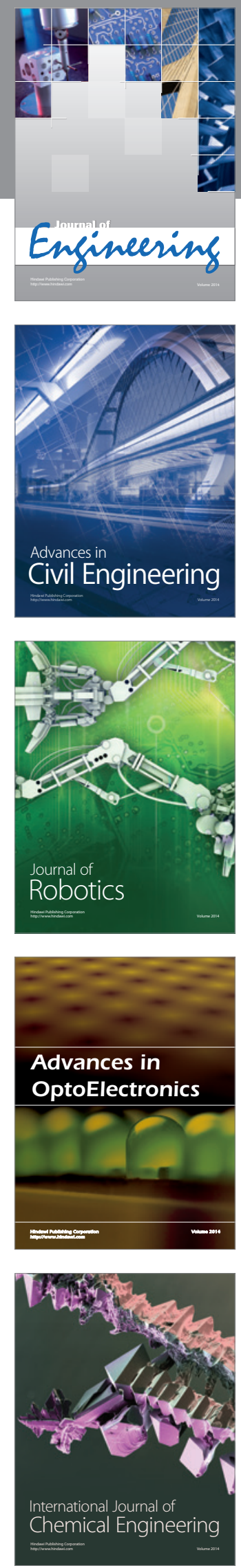

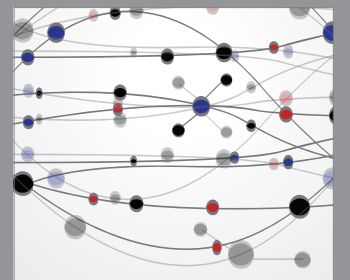

The Scientific World Journal
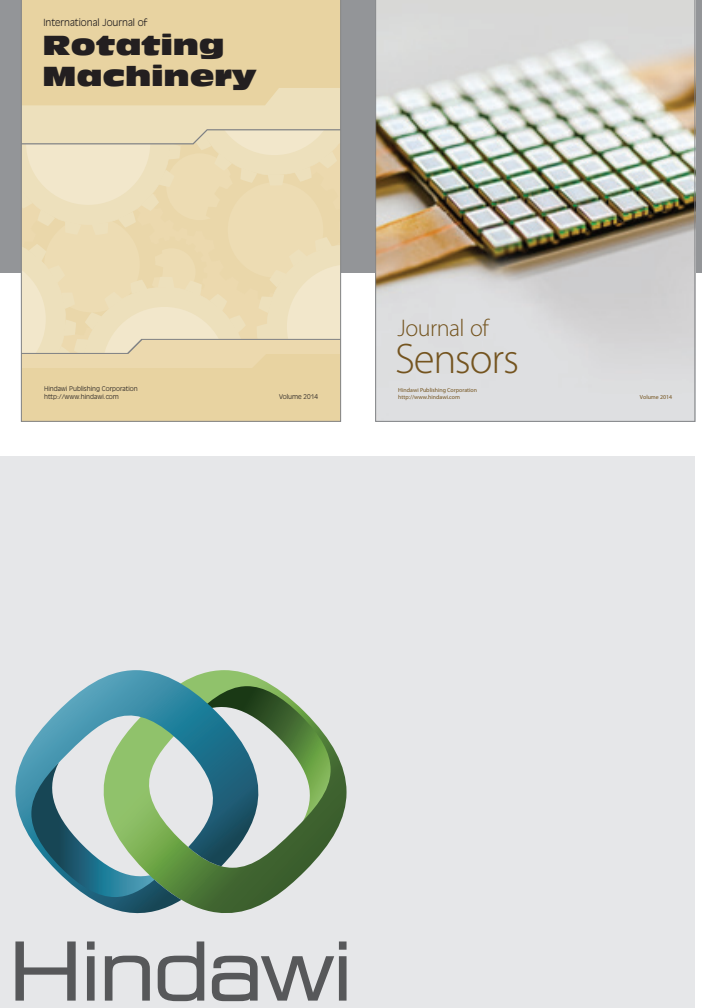

Submit your manuscripts at http://www.hindawi.com
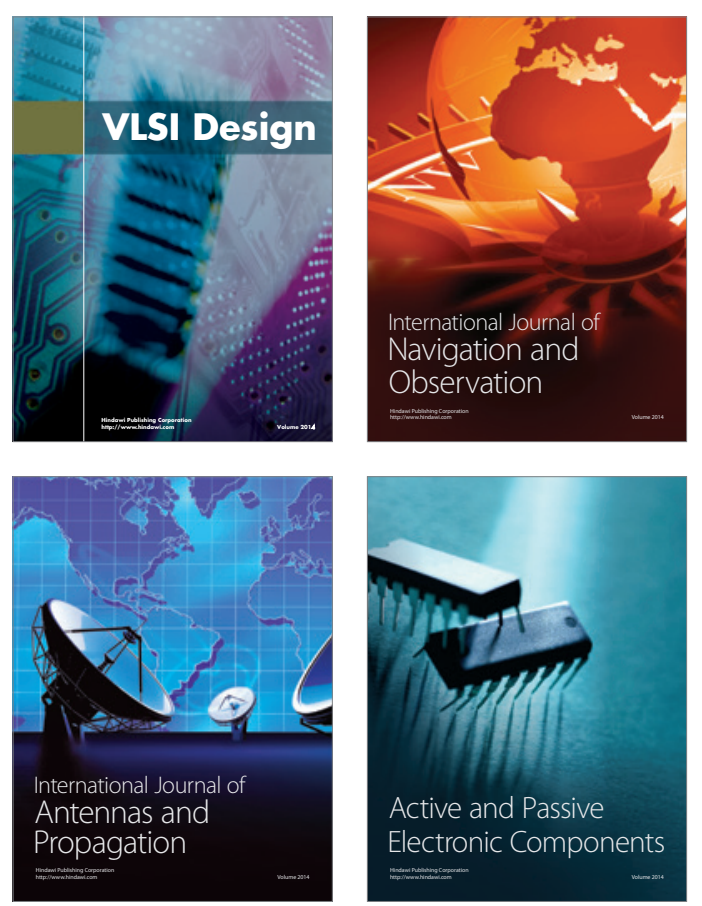
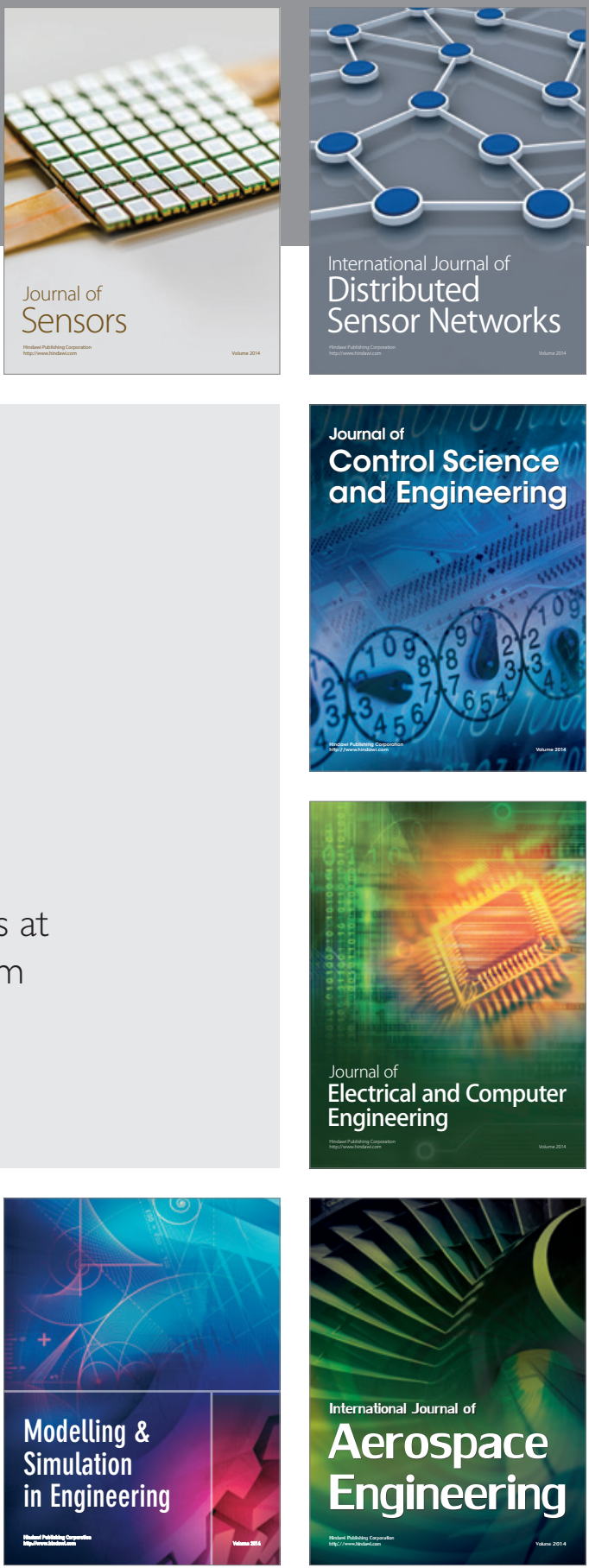

Journal of

Control Science

and Engineering
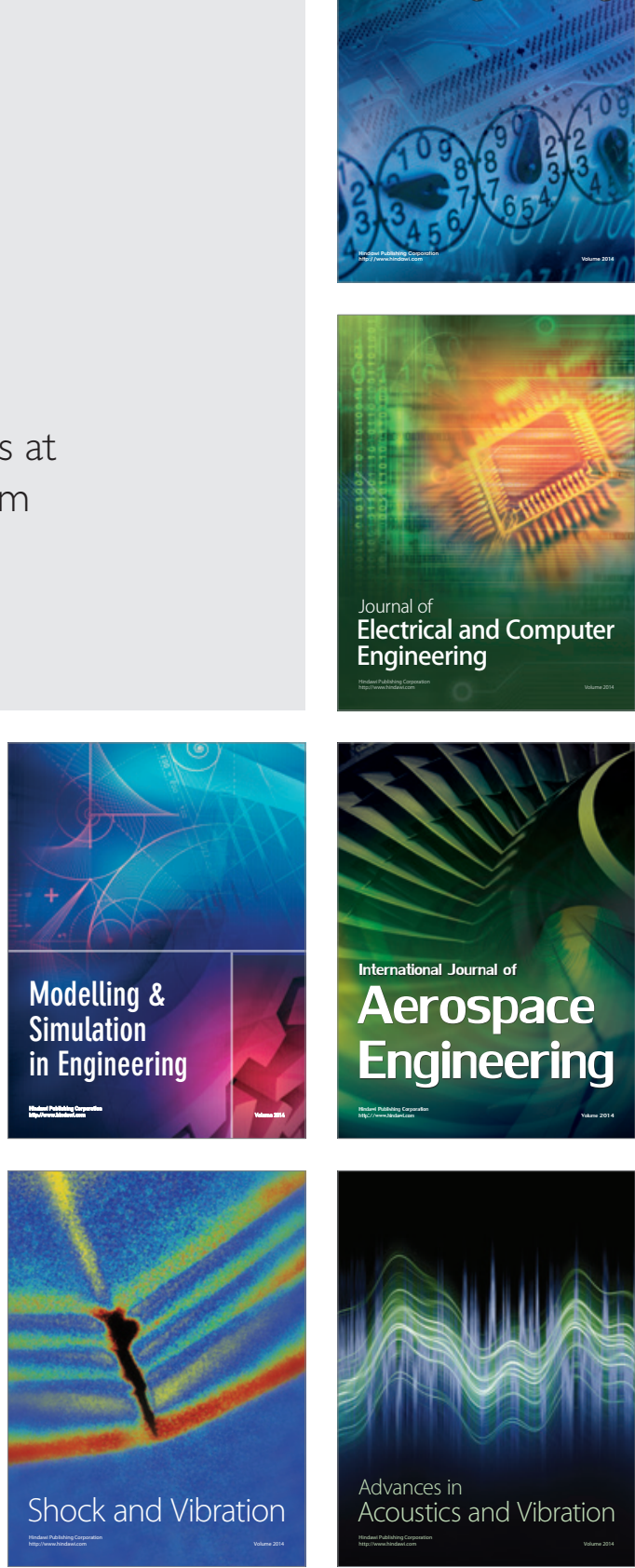